\title{
REPREZENTATYWNOŚĆ W SPORACH ZBIOROWYCH - NIEDOKOŃCZONA (R)EWOLUCJA?
}

\author{
Abstract \\ Representativeness in collective disputes: Unfinished ( $r$ )evolution?
}

The amendment to the trade union act, which entered into force on January 1, 2019, has undoubtedly made the most far-reaching changes in collective labour law since at least the late 1980s and early 1990s. One of the structures that has undergone transformations is the representativeness of trade unions at various levels. At the same time, the legislator amended the Act on the settlement of collective disputes, however, he has not decided to introduce representativeness to it as one of the requirements for conducting a collective dispute. The study is intended to attempt to answer the question whether this abstinence is justified or whether further changes to this act should be postulated, including in terms of taking into account the diversity of rights of trade union structures due to having representativeness.

Słowa kluczowe: związki zawodowe, spory zbiorowe, reprezentatywność, zbiorowe prawo pracy

Keywords: trade unions, collective dispute, representativeness, collective labour law

ASJC: 3308, JEL: K31

\section{Uwagi wstępne}

Wyrok Trybunału Konstytucyjnego z dnia 2 czerwca 2015 roku (K 1/13, Dz.U. 2015, poz. 791) wywołał reperkusje w całym zbiorowym prawie pracy. Jego realizacja nie mogła bowiem polegać wyłącznie na prostej zmianie art. 2 ustawy z dnia 23 maja 1991 roku o związkach zawodowych (Dz.U. 2019, poz. 263 tekst jedn. ze zm., dalej: ustawa o związkach zawodowych, u.z.z.), lecz niosła ze sobą konieczność modyfikacji, a niekiedy wręcz przebudowy znacznej części konstrukcji prawnych, dotychczas tworzonych zasadniczo z myślą o pracownikach.

Można wskazać, że zmiany, które weszły w życie na początku ubiegłego roku, miały dwojaki charakter. Po pierwsze w nowej formule ruchu związkowego konieczne stało się uwzględnienie tego, że obecnie członkami związków zawodowych mogą być także 
inne niż pracownicy osoby wykonujące pracę zarobkową (zob. art. $1^{1}$ pkt 1 u.z.z.; Baran 2018a, s. 3; Grzebyk 2019, s. 165 i n.; Pisarczyk 2019, s. 244 i n. wraz z przywołaną tam literaturą; co prawda, przed nowelizacją również osoby pozostające poza stosunkiem pracy miały przyznane prawo koalicji, jednakże dotyczyło to wąskiego i zamkniętego katalogu kategorii tytułów prawnych wykonywania pracy, które miały marginalne znaczenie praktyczne). Dotychczasowe rozwiązania nie przystawały bowiem do zupełnie odmiennych mechanizmów prawnych dotyczących ich aktywności zawodowej. Innymi słowy, znaczna część nowych rozwiązań jest bezpośrednią konsekwencją przyjęcia nowej, wolnościowej formuły prawa koalicji. Przykładem tego typu kwestii może być zagadnienie ochrony działaczy związkowych niebędących pracownikami (Baran 2018b, s. 21; Dral 2018, s. 243). Po drugie tą samą nowelizacją ustawodawca wprowadził zmiany także w niektórych konstrukcjach, które nie mają bezpośredniego związku z wyrokiem Trybunału Konstytucyjnego. Tutaj przykładem może być zmiana art. 28 u.z.z., w wyniku której poszerzony został zakres informacji, które pracodawca ma przekazywać organizacjom zakładowym (Szmit 2019b, s. 36). Do tej kategorii zmian należy także zaliczyć wprowadzenie mechanizmu weryfikacji oświadczeń o liczebności zakładowych organizacji związkowych (art. $25^{1}$ u.z.z.).

Uwzględniając powyższe zróżnicowanie wprowadzonych zmian, na szczególną uwagę zasługują te, które dotknęły konstrukcję reprezentatywności związkowej. Co oczywiste, rozszerzony został katalog członków organizacji związkowych uwzględnianych w liczbie, od której zależy uzyskanie tego przymiotu (co jest realizacją wyroku Trybunału Konstytucyjnego). Jednocześnie jednak ustawodawca zmodyfikował parametry procentowe związane z uzyskaniem reprezentatywności na poziomie ponadzakładowym i zakładowym, a także zdecydował się na inne zmiany, czego przykładem jest chociażby wprowadzenie tak zwanej reprezentatywności łącznej. W miarę bezpiecznie można zatem przyjąć, że w kontekście reprezentatywności nowelizacja z dnia 5 lipca 2018 roku (ustawa o zmianie ustawy o związkach zawodowych oraz niektórych innych ustaw, Dz.U. 2018, poz. 1608, dalej: ustawa nowelizująca) stała się okazją do dosyć daleko idącego przemodelowania dotychczasowych konstrukcji. To spostrzeżenie daje z kolei asumpt do pytania o ocenę konstrukcji reprezentatywności przez pryzmat ustawy z dnia 23 maja 1991 roku o rozwiązywaniu sporów zbiorowych (Dz.U 2019, poz. 174 tekst jedn. ze zm., dalej: ustawa o rozwiązywaniu sporów zbiorowych, u.r.s.z.).

\section{Reprezentacja związkowa w sporze zbiorowym w razie wielości organizacji związkowych u jednego pracodawcy - stan de lege lata i uwagi de lege ferenda}

Ustawa o rozwiązywaniu sporów zbiorowych była jednym z aktów, które objęła nowelizacja ustawy o związkach zawodowych. Zmiany tego aktu ograniczyły się jednak wyłącznie do jednego aspektu, to jest przyznania prawa do prowadzenia sporów zbiorowych, w tym akcji strajkowej, wszystkim osobom wykonującym pracę zarobkową (art. 6 u.z.z.). 
Ustawodawca nie zdecydował się zatem na głębsze zmiany, pomimo tego że odnaleźć można liczne sygnały i głosy wskazujące na taką potrzebę. Analiza wypowiedzi przedstawicieli doktryny, a także najbardziej zainteresowanych, czyli partnerów społecznych, pozwala wskazać, że przykładem takiej zmiany jest między innymi wprowadzenie uprzedniej kontroli sądowej legalności zarówno całego sporu zbiorowego, jak i samego strajku (o potrzebie takiej kontroli może świadczyć poszukiwanie w obecnym stanie prawnym podstawy do takich działań w art. 189 ustawy z dnia 17 listopada 1964 roku - Kodeks postępowania cywilnego, Dz.U. 2019, poz. 1460 tekst jedn. ze zm.; zob. Kurzynoga 2014, s. 16, Świątkowski 2014, s. 1134 i n.). Być może ograniczenie aktywności ustawodawcy w tym zakresie należy tłumaczyć założeniem, że i tak zbiorowe prawo pracy zostało wprowadzone na nowe tory i daleko idąca zmiana istotnej składowej tej części prawa pracy, jaką są spory zbiorowe, została uznana przez ustawodawcę za zbyt daleko idące przekształcenie relacji między partnerami społecznymi. Ewentualnie bardziej prozaicznym wyjaśnieniem tego stanu rzeczy może być skupienie się przez ustawodawcę na nowelizacji samej ustawy o związkach zawodowych i minimalistyczne postrzeganie konieczności dokonania zmian w innych aktach prawnych (na przykład w ustawie z dnia 26 czerwca 1974 roku - Kodeks pracy, Dz.U. 2019, poz. 1040 tekst jedn. ze zm., dalej: k.p.; czy też w ustawie z dnia 24 lipca 2015 roku o Radzie Dialogu Społecznego i innych instytucjach dialogu społecznego, Dz.U. 2018, poz. 2232 tekst jedn. ze zm.).

Niniejsze opracowanie ma na celu poddanie analizie kwestii zasadności dokonania kolejnej nowelizacji ustawy o rozwiązywaniu sporów zbiorowych, której przedmiotem byłoby wprowadzenie konstrukcji reprezentatywności związkowej do sfery sporów zbiorowych. Prowadzenie tego typu rozważań i formułowanie w tym temacie uwag wydaje się zasadne nie tylko z teoretycznego, ale również z praktycznego punktu widzenia. Wynika to z tego, że uwzględniając wskazywane już głosy przedstawicieli praktyki i teorii oraz niektóre działania podejmowane przez organy publiczne, na przykład wypowiedzi przedstawicieli Ministerstwa Rodziny Pracy i Polityki Społecznej czy też członków Rady Dialogu Społecznego, można założyć, że duża nowelizacja tego aktu jest prawdopodobna. Należy podkreślić, że dalsze uwagi będą ograniczone wyłącznie do sporów zakładowych, z pominięciem sporów ponadzakładowych ${ }^{1}$.

De lege lata każda organizacja związkowa, bez względu na swoją liczebność, ma możliwość prowadzenia rokowań, mediacji i arbitrażu, a także (po uzyskaniu poparcia załogi) zorganizowania strajku.

${ }^{1}$ Ogólna liczba wszystkich sporów zbiorowych w Polsce nie jest wysoka. Według sprawozdania Głównego Inspektora Pracy za rok 2018 było ich trzysta pięćdziesiąt cztery, w tym sto czterdzieści trzy w sektorze opieki zdrowotnej i pomocy społecznej (PIP 2019, s. 306). Co prawda, rok wcześniej sporów zgłoszono dziewięć tysięcy czterysta dziewięćdziesiąt dwa, ale dziewięć tysięcy czterdzieści sześć z nich stanowiły spory w sektorze edukacji (PIP 2018, s. 214). Z kolei według GUS-u liczba strajków w tych latach wyniosła odpowiednio: siedem w roku 2018 oraz tysiąc pięćset pięćdziesiąt sześć w roku 2017 (GUS 2019, s. 133). Można przy tym bezpiecznie założyć, że wśród tych sporów zbiorowych spory ponadzakładowe stanowiły bardzo niewielki odsetek. 
Obowiązujące rozwiązanie ma swoje zalety. Bez wątpienia jest to najdalej idąca realizacja założenia o równości związków zawodowych, a nawet wskazanego w art. 1 ust. 3 u.z.z. nakazu jednakowego traktowania wszystkich związków zawodowych (zupełnie odrębną kwestią jest ocena prawidłowości tej konstrukcji, lecz jest to zagadnienie daleko wykraczające poza ramy niniejszego opracowania). Ponadto stwarza ono możliwość nawet stosunkowo niewielkiej grupie zatrudnionych podjęcia działań, które będą zmierzały do poprawienia ich sytuacji. Można wskazać, że nabiera to szczególnego znaczenia, wówczas gdy u danego pracodawcy zatrudnione są różne grupy zawodowe, o często rozbieżnych interesach, a jedna z nich jest wyraźnie mniej liczna.

W doktrynie zauważa się, że spory zbiorowe są swoistym wyjątkiem pośród ogółu instrumentów służących układaniu relacji między pracodawcą a stroną związkową w sytuacji wielości podmiotów po stronie związkowej (Florek 2017, s. 320). Można bowiem wskazać, że zasadą w takich okolicznościach jest przyjęcie konstrukcji reprezentatywności (Stelina 2018, s. 601). Należy mieć przy tym na względzie to, że reprezentatywność jest stosowana, kiedy ustawodawca narzuca stronie związkowej wspólne działanie, to znaczy gdy zakłada, iż organizacje związkowe dla skuteczności swojego działania będą reprezentowały wspólne stanowisko. Reprezentatywność ma zatem doprowadzić do ograniczenia po stronie związkowej liczby podmiotów, których głos jest istotny, co w założeniu ma zwiększyć prawdopodobieństwo wypracowania przez nie wspólnego stanowiska. Co więcej, często jest to powiązane ze swoistą ,sankcją, jaką jest prawo pracodawcy do podejmowania decyzji samodzielnie w razie braku wspólnego stanowiska co najmniej organizacji reprezentatywnych (najdobitniej wyraża to art. 30 ust. 6 u.z.z.). Siłą rzeczy powyższe założenie dotyczy spraw o charakterze zbiorowym, a nie indywidualnym, a spory zbiorowe oczywiście mieszczą się w tej kategorii (co zresztą bezpośrednio wynika z art. 4 ust. 1 u.z.z.).

Rozważając ideę reprezentatywności, można zresztą wskazać kilka aksjologicznych uzasadnień posługiwania się nią. Na potrzeby dalszych rozważań uwaga skupi się na dwóch. Pierwszą jest wspomniane wyżej dążenie do zwiększenia jednolitości stanowiska wyrażanego przez stronę pracowniczą. Drugą zaś uznanie, że niektóre z organizacji związkowych legitymują się silniejszym mandatem nie tylko do reprezentowania interesów swoich członków, ale przede wszystkim do reprezentowania interesów całej załogi, w tym osób niezrzeszonych, a nawet zrzeszonych w innych organizacjach związkowych.

Przed przejściem do szczegółowych uwag warto jeszcze rozróżnić dwa aspekty sporu zbiorowego: samo jego rozpoczęcie, a dokładnie rzecz biorąc - prowadzenie rokowań i mediacji (a także ewentualnego arbitrażu) oraz organizację strajku. Jako kluczową dla dalszych rozważań różnicę między etapami pokojowymi a strajkiem należy uznać ich potencjalnie negatywny wpływ na sytuację załogi rozumianej jako ogół zatrudnionych. W przypadku rokowań i mediacji trudno właściwie wskazać, że taka możliwość istnieje. Wręcz odwrotnie - albo ich prowadzenie nie będzie mieć na zatrudnionych większego wpływu, albo (w optymistycznym wariancie) doprowadzi do polepszenia warunków pracy, płacy lub świadczeń socjalnych. Inaczej przedstawia się sytuacja w przypadku strajku - zatrzymanie części lub całości pracy w wyniku takiej akcji nie tylko odbija się na tych, którzy zdecydowali się wziąć w nim udział, ale 
też może oddziaływać na osoby, które podjęły odmienną decyzję, a nawet mogły być mu zdecydowanie przeciwne.

Jak już zostało wskazane, w obecnym modelu wszczęcie sporu może zostać zrealizowane przez każdą organizację zakładową (a ponadto - zgodnie $\mathrm{z}$ art. 3 ust. 4 u.r.s.z. możliwość taka przysługuje organizacji związkowej spoza zakładu pracy, jeżeli z takim wnioskiem zwrócą się do niej sami zatrudnieni). Tym samym ustawodawca przyjmuje, że w stosunku do etapów pokojowych organizator sporu nie musi legitymować się żadnym szczególnym mandatem do podjęcia tych czynności, a wystarczy jedynie zrzeszanie co najmniej dziesięciu osób wykonujących pracę zarobkową zatrudnionych u danego pracodawcy (w przypadku organizacji międzyzakładowej może to być nawet w skrajnym wypadku zaledwie jedna osoba). Wydaje się, że uzasadnieniem tego rozwiązania jest wskazywana niska bądź żadna dolegliwość tego stanu rzeczy dla załogi. Tym samym można założyć, że jedna z przesłanek posłużenia się konstrukcją reprezentatywności (legitymowanie się odpowiednim mandatem) może być pominięta w kontekście wszczęcia sporu zbiorowego (innymi słowy, brak jest konieczności odwoływania się do reprezentatywności ze względu na legitymizację działań organizacji związkowej).

Pozostaje jeszcze kwestia swoistego „uporządkowania” strony związkowej, zminimalizowania nie zawsze pozytywnych skutków pluralizmu związkowego. Wydaje się, że w tym wypadku obecny model nie sprzyja temu celowi. Co więcej, rozwiązania de lege lata mogą wręcz prowadzić do zjawisk, które zdecydowanie należy ocenić jako niepożądane. Przykładem może być możliwość toczenia jednocześnie wielu sporów, o zbliżonym albo wręcz identycznym przedmiocie. Zjawisko to jest negatywne z punktu widzenia nie tylko pracodawcy, ale także strony pracowniczej, która może mieć problemy ze zrozumieniem aktualnej sytuacji w zakładzie pracy. Powstająca w takich okolicznościach swoista nerwowość z pewnością nie jest stanem pożądanym przez zatrudnionych. Co więcej, warto zwrócić w tym kontekście uwagę na istotną zasadę ograniczającą prowadzenie sporów, to jest klauzulę pokoju społecznego, zawartą w art. 4 ust. 2 u.r.s.z. $(\mathrm{Cu}-$ dowski 1998, s. 131). Jej założenie jest proste - w sprawach, w których zawarte zostało porozumienie (czy to w formie układu zbiorowego, czy innego porozumienia). spory zbiorowe są wyłączone ${ }^{2}$. Zasadniczo jest to formuła chroniąca interesy pracodawcy, lecz w szerszym ujęciu może być istotna dla pracowników. Otóż można zakładać, że pracodawca powinien wykazywać większą chęć do zawarcia porozumienia (które w świetle art. 9 k.p. wiąże się z przyznaniem pracownikom dodatkowych uprawnień lub zmniejszeniem obowiązków względem stanu ustawowego), jeżeli ma gwarancję, że w danej materii nie będzie „groził” mu spór z załogą (oczywiście do czasu wypowiedzenia

2 Dotyczy to sporów o zmianę treści układu lub porozumienia, a nie zakazu prowadzenia sporu w przedmiocie nieprzestrzegania jego postanowień (Rączka 1996, s. 56). Podobnie nie stanowi naruszenia tej zasady wszczęcie sporu, którego celem będzie taka zmiana warunków pracy lub płacy, która nie powoduje konieczności zmiany treści układu lub porozumienia (na przykład podwyżki o kwotę, która nie spowoduje przekroczenia przewidzianych w układzie górnej granicy widełek wynagrodzeń w danej grupie zawodowej). 
danego układu lub porozumienia; inna sprawa, że formuła ta jest niekiedy nadużywana przez pracodawców).

Kolejną problematyczną kwestią, którą też warto w tym miejscu zasygnalizować, jest potencjalny problem $\mathrm{z}$ ustaleniem, jakie prawo zakładowe obowiązuje wówczas, gdy w danej materii uregulowanej już na przykład układem zbiorowym pracy zawarte zostanie późniejsze porozumienie z organizacją niebędącą stroną tego układu, którego postanowienia będą odmienne od układowych, zwłaszcza gdy będą one odbiegać od nich na niekorzyść pracowników. Problemy mogą też wreszcie rodzić się wtedy, gdy toczone są dwa spory dotyczące podobnej kwestii, a zawarte porozumienia mają odmienną treść.

Z tego punktu widzenia stan, w którym każda organizacja zakładowa, w szczególności niebędąca stroną dotychczasowych ustaleń, może rozpocząć spór zbiorowy, należy ocenić negatywnie.

W konsekwencji przyznanie prawa rozpoczęcia sporu zbiorowego wyłącznie organizacjom reprezentatywnym, a zatem zazwyczaj nie wszystkim działającym u danego pracodawcy, może być traktowane jako instrument wzmacniający klauzulę pokoju społecznego oraz wpływać porządkująco na system aktów zakładowego prawa pracy, co ostatecznie należy uznać za stan korzystny zarówno dla załogi, jak i dla pracodawcy.

W tym miejscu warto zwrócić uwagę na to, że mechanizmem, który z jednej strony nie ograniczałby zbyt radykalnie liczby organizacji związkowych wyposażonych w kompetencję wszczęcia sporu zbiorowego, a z drugiej uwzględniał korzyści z jej zmniejszenia, mogłaby być konstrukcja reprezentatywności łącznej, czyli takiej, którą mogłyby uzyskać mniejsze organizacje, występując łącznie jako jedna na potrzeby sporu. Mechanizm taki został już zresztą częściowo wprowadzony do systemu zbiorowego prawa pracy z dniem 1 stycznia 2019 roku w art. $25^{3}$ ust. 3-5 u.z.z. Obecnie jest on ograniczony wyłącznie do tych organizacji, które należą do jednej federacji lub jednej konfederacji, lecz rozwiązanie to z powodzeniem można byłoby rozszerzyć także na inne organizacje (formuła ta spotkała się z różnym przyjęciem u przedstawicieli doktryny. Jej pozytywne walory dostrzegają między innymi: Lekston 2019, s. 150; Szmit 2019a, s. 29. Z kolei negatywną ocenę wyrażają między innymi: Latos-Miłkowska 2019, s. 5; Pisarczyk 2019, s. 375). Warto jednak podkreślić, że w odróżnieniu od mechanizmu przyjętego w ustawie o związkach zawodowych w tym wypadku mowa byłaby o dobrowolnej decyzji organizacji związkowych w zakresie skorzystania z reprezentatywności łącznej, zatem nie byłby to mechanizm narzucany przez ustawodawcę.

Przechodząc do etapu strajku, wydaje się, że w tym wypadku na pierwszy plan zdecydowanie wysuwa się kwestia mandatu pochodzącego od załogi do jego zorganizowania. Obowiązujące aktualnie rozwiązanie opiera się na referendum, dla którego ważności musi zostać osiągnięte odpowiednie kworum oraz odpowiednia większość głosów. Bez wątpienia jest to mechanizm o wysokim stopniu demokratyzacji, co samo w sobie należy uznać za dużą wartość. Przy obecnych progach procentowych decydujących o uzyskaniu statusu organizacji reprezentatywnej na poziomie zakładowym trudno byłoby przyjąć, że sama reprezentatywność daje wystarczający mandat do organizowania 
strajku, zwłaszcza mając na uwadze wskazywaną wcześniej możliwość wywołania nim negatywnych konsekwencji nie tylko dla osób strajkujących, ale przede wszystkim dla tych, którzy do tej akcji się nie przyłączą.

Także w odniesieniu do zmniejszenia liczby organizacji związkowych, które mogłyby zorganizować strajk, trudno znaleźć argument za odwołaniem się do konstrukcji reprezentatywności. Miałoby to bowiem znaczenie jedynie wówczas, gdyby ustawodawca zdecydował się na zniesienie wymogu referendum, co wydaje się wysoce nieprawdopodobne ${ }^{3}$. Tak długo bowiem, jak referendum jest wymagane, to sama załoga ma ostateczny głos w tej kwestii.

Warto także w tym miejscu wskazać, iż Europejski Komitet Praw Społecznych uznał, że „za sprzeczne z EKS uznać należy wszelkie regulacje, zgodnie z którymi strajki mogą być organizowane jedynie przez reprezentatywne (duże) związki zawodowe" (zob. na przykład Konkluzje XV-1 Niemcy Artykuł 6-4, Konkluzje 2014 Francja Artykuł 6-4, Konkluzje 2010 Rumunia Artykuł 6-44). Jest to dodatkowy argument za przyjęciem, że w stosunku do strajku oparcie możliwości jego zorganizowania wyłącznie na przesłance reprezentatywności nie wydaje się zasadne ${ }^{5}$.

\section{Uwagi podsumowujące}

Ustawa nowelizująca wprowadziła nową jakość do krajowego zbiorowego prawa pracy. Wprowadzone rozwiązania dotknęły przy tym między innymi sferę sporów zbiorowych oraz istotnych elementów konstrukcji reprezentatywności organizacji związkowych. Zmiany w tych płaszczyznach przebiegły jednakże niezależnie od siebie. Innymi słowy, ustawodawca nie zdecydował się na włączenie sporów zbiorowych do kategorii relacji na linii pracodawca - reprezentacja związkowa, w których rolę odgrywa reprezentatywność. Powoduje to, że nadal otwarte pozostaje pytanie o celowość podjęcia takiego kroku.

${ }^{3}$ Warto wskazać, że rozwiązanie polegające na odwołaniu się do woli załogi jako warunku koniecznego wszczęcia strajku nie tylko funkcjonuje w niezmienionej formie od wejścia w życie ustawy o rozwiązywaniu sporów zbiorowych, ale też zostało wprowadzone do rodzimego systemu już od początku swoistego reaktywowania legalności sporów zbiorowych po drugiej wojnie światowej. Mianowicie już w ustawie o związkach zawodowych z dnia 8 października 1982 roku (Dz.U. 1982, nr 32, poz. 216) w art. 38 ust. 1 (tekstu pierwotnego) ustawodawca wskazał, że strajk ogłasza zakładowy organ związku po uzyskaniu akceptacji tej decyzji przez większość załogi w głosowaniu tajnym oraz zgody nadrzędnego organu związku.

${ }^{4}$ Zob. odpowiednio: Niemcy 2001; Francja 2014; Rumunia 2010.

${ }^{5}$ Co prawda, Polska nie jest związana art. 6 ust. 4 Europejskiej karty społecznej (Dz.U. 1999, nr 8, poz. 67), co powoduje, że „dorobek EKPS w zakresie prawa do strajku nie jest wiążący dla Polski. [...] [a opinie tego ciała - przyp. J.S.] mogą służyć ustawodawcy polskiemu jedynie jako źródło inspiracji do zmian istniejących przepisów [...]" (Grzebyk 2019, s. 66). Nawet jednak tak słabe oddziaływanie opinii Europejskiego Komitetu Praw Społecznych nie stoi na przeszkodzie potraktowania go jako jednego $\mathrm{z}$ elementów analizy przedmiotowego zagadnienia. 
Podsumowując przeprowadzone w niniejszym opracowaniu rozważania, wydaje się, że za zasadne można uznać częściowe rozciągnięcie stosowania konstrukcji reprezentatywności na sferę sporów zbiorowych. Ze względu na przesłanki posługiwania się nią oraz uwzględniając konieczność odrębnej oceny w tym względzie etapów pokojowych sporu zbiorowego oraz strajku, można de lege ferenda postulować przyznanie wyłącznego prawa wszczęcia sporu zbiorowego organizacjom reprezentatywnym, przy czym dopuścić należy wówczas także możliwość posługiwania się reprezentatywnością łączną, o charakterze dobrowolnym.

Dużo więcej wątpliwości budzi jednak przyznanie prawa organizacji strajku danej organizacji wyłącznie ze względu na jej reprezentatywność, z pominięciem instytucji referendum. Wątpliwości te są tak silne, że właściwie należy opowiedzieć się przeciwko takiej możliwości (a przynajmniej do momentu, gdy ewentualnie całkowicie zmieniona zostanie formuła reprezentatywności na poziomie zakładowym, na przykład przez przyjęcie głosowania załogi jako przesłanki jej uzyskania przez zakładową organizację związkową).

Wydaje się, iż stanowisko Europejskiego Komitetu Praw Społecznych przytoczone wyżej byłoby do pogodzenia z zaproponowanym rozwiązaniem, jako że po pierwsze także mniejsze organizacje mogłyby doprowadzić do strajku, a po drugie i tak kluczowa byłaby wola załogi w tej materii.

Kończąc, warto jeszcze zwrócić uwagę, że w projekcie Kodeksu zbiorowego prawa pracy (Departament Prawa Pracy 2018) zaproponowano ewolucyjne zmiany w zakresie sporów zbiorowych. Zostały one już przybliżone w literaturze (Szmit 2018, s. 8), stąd w tym miejscu wystarczy poprzestać jedynie na wskazaniu, że w sytuacji mnogości przedstawicielstw związkowych projekt przewidywał wprowadzenie zasady, że warunkiem wszczęcia sporu jest albo wyłonienie wspólnej reprezentacji przez stronę związkową, albo wystąpienie z żądaniami do pracodawcy przez co najmniej jedno reprezentatywne zakładowe przedstawicielstwo związkowe. $\mathrm{W}$ tej sytuacji spór prowadzić miały przedstawicielstwa reprezentatywne, które go wszczęły, a pozostałe przedstawicielstwa mogły przystąpić do rokowań. Wiązało się to zresztą ze zmienioną koncepcją reprezentatywności oraz zmodyfikowanymi zasadami dotyczącymi zawierania układów zbiorowych pracy. Ponadto projekt utrzymywał wymóg referendum jako przesłanki legalnego strajku. Tym samym Komisja Kodyfikacyjna dostrzegła potrzebę zmiany obowiązującej de lege lata formuły w zakresie podmiotów uprawnionych do wszczynania sporów zbiorowych i zaproponowała rozwiązania mające w jej mniemaniu stanowić usunięcie zdiagnozowanych nieprawidłowości.

\section{Bibliografia}

Baran K.W. (2018a) O zakresie prawa koalicji w zwiazkach zawodowych po nowelizacji prawa związkowego, „Praca i Zabezpieczenie Społeczne”, nr 9.

Baran K.W. (2018b) Refleksje o ochronie stosunku zatrudnienia działaczy związkowych na poziomie zakładowym po nowelizacji ustawy związkowej z 5 lipca 2018 roku, „Praca i Zabezpieczenie Społeczne", nr 10. 
Cudowski B. (1998) Spory zbiorowe w polskim prawie pracy, Białystok.

Departament Prawa Pracy (2018) Teksty projektu Kodeksu pracy i projektu Kodeksu zbiorowego prawa pracy opracowane przez Komisję Kodyfikacyjną Prawa Pracy, https://www.gov.pl/ web/rodzina/bip-teksty-projektu-kodeksu-pracy-i-projektu-kodeksu-zbiorowego-prawa-pracy-opracowane-przez-komisje-kodyfikacyjna-prawa-pracy (dostęp: 3 kwietnia 2020).

Dral A. (2018) Ochrona trwałości stosunku pracy działaczy związkowych w świetle noweli ustawy o związkach zawodowych, „Studia z Zakresu Prawa Pracy i Polityki Społecznej”, nr 3.

Florek L. (2017) Prawo pracy, Warszawa.

Grzebyk P. (2019) Od rządów siły do rządów prawa. Polski model prawa do strajku na tle standardów unijnego i międzynarodowego prawa pracy, Warszawa.

GUS (2019) Mały rocznik statystyczny Polski 2019, Warszawa.

Kurzynoga M. (2014) Prawo pracodawcy do wystąienia z powództwem o ustalenie nielegalności strajku i wnioskiem o zabezpieczenie roszczenia $w$ drodze zakazu zorganizowania strajku, „Praca i Zabezpieczenie Społeczne”, nr 5.

Latos-Miłkowska M. (2019) Reprezentatywność zakładowych organizacji związkowych po nowelizacji ustawy o zwiazkach zawodowych - nowa jakość czy stracona szansa?, „Praca i Zabezpieczenie Społeczne", nr 5.

Lekston M. (2019) Komentarz do art. 253 ustawy o zwiazkach zawodowych [w:] K.W. Baran (red.), Zbiorowe prawo zatrudnienia. Komentarz, Warszawa.

PIP (2018) Sprawozdanie z działalności Państwowej Inspekcji Pracy w 2017 roku, https://www. pip.gov.pl/pl/f/v/192642/Sprawozdanie\%20z\%20dzialalnosci\%20PIP\%20w\%202017.pdf (dostęp: 4 kwietnia 2020).

PIP (2019) Sprawozdanie z działalności Państwowej Inspekcji Pracy w 2018 roku, https://www. pip.gov.pl/pl/f/v/211637/Sprawozdanie\%202018\%20r (dostęp: 4 kwietnia 2020).

Pisarczyk Ł. (2019) Reforma zbiorowego prawa pracy. Próba kodyfikacji a nowelizacja przepisów zbiorowego prawa pracy, Warszawa.

Rączka K. (1996) Kilka uwag w sprawie legalności sporu zbiorowego, „Praca i Zabezpieczenie Społeczne", nr 2.

Stelina J. (2018) Zbiorowe prawo pracy [w:] J. Stelina (red.), Prawo pracy, Warszawa.

Szmit J. (2018) Spory zbiorowe w projekcie Kodeksu zbiorowego prawa pracy, „Praca i Zabezpieczenie Społeczne", nr 7.

Szmit J. (2019a) Reprezentatywność zakładowej organizacji związkowej w świetle nowelizacji ustawy o zwiazkach zawodowych, „Praca i Zabezpieczenie Społeczne”, nr 3.

Szmit J. (2019b) Obowiazki informacyjne pracodawcy wobec przedstawicielstwa związkowego, „Praca i Zabezpieczenie Społeczne”, nr 11.

Świątkowski A.M. (2014) Wymiar sprawiedliwości w zbiorowym prawie pracy [w:] K.W. Baran (red.), System prawa pracy, t. 5: Zbiorowe prawo pracy, Warszawa.

\section{Orzecznictwo}

Niemcy (2001) http://hudoc.esc.coe.int/eng?i=XV-1/def/DEU/6/4/EN (dostęp: 7 kwietnia 2020). Rumunia (2010) http://hudoc.esc.coe.int/eng?i=2010/def/ROU/6/4/EN (dostęp: 7 kwietnia 2020). 
Francja (2014) http://hudoc.esc.coe.int/eng?i=2014/def/FRA/6/4/EN (dostęp: 7 kwietnia 2020). Wyrok Trybunału Konstytucyjnego z dnia 2 czerwca 2015 roku, K 1/13, Dz.U. 2015, poz. 791.

\section{Akty prawne}

Europejska karta społeczna sporządzona w Turynie dnia 18 października 1961 roku, Dz.U. 1999, nr 8, poz. 67.

Ustawa z dnia 17 listopada 1964 roku - Kodeks postępowania cywilnego, Dz.U. 2019, poz. 1460 tekst jedn. ze zm.

Ustawa z dnia 26 czerwca 1974 roku - Kodeks pracy, Dz.U. 2019, poz. 1040 tekst jedn. ze zm. Ustawa z dnia 8 października 1982 roku o związkach zawodowych, Dz.U. 1982, nr 32, poz. 216. Ustawa z dnia 23 maja 1991 roku o rozwiązywaniu sporów zbiorowych, Dz.U 2019, poz. 174 tekst jedn. ze zm.

Ustawa z dnia 23 maja 1991 roku o związkach zawodowych, Dz.U. 2019, poz. 263 tekst jedn. ze $\mathrm{zm}$.

Ustawie z dnia 24 lipca 2015 roku o Radzie Dialogu Społecznego i innych instytucjach dialogu społecznego, Dz.U. 2018, poz. 2232 tekst jedn. ze zm.

Ustawa z dnia 5 lipca 2018 roku o zmianie ustawy o związkach zawodowych oraz niektórych innych ustaw, Dz.U. 2018, poz. 1608. 